\title{
Simplex Lattice Design Models for the Determination of Modulus of Rupture of Concretes
}

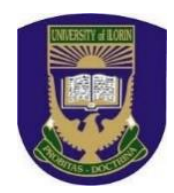

\author{
J. I. Arimanwa ${ }^{1}$, D.O. Onwuka ${ }^{1}$, M. C. Arimanwa ${ }^{2}$, C. A. Ajoku ${ }^{1 *}$ \\ ${ }^{1}$ Department of Civil Engineering, Federal University of Technology Owerri, Nigeria. \\ ${ }^{2}$ Department of Civil Engineering, Federal Polytechnic Nekede, Nigeria.
}

ABSTRACT: This work aims at assessing the suitability of run-off sand for concrete production and presents Simplex Lattice Design models for the determination of Modulus of Rupture of Concrete. Fine aggregates obtained from five different sources tagged Samples A, B, C, D and E were used to produce concrete beams referred to as Concrete A, Concrete B, Concrete $\mathrm{C}$, Concrete $\mathrm{D}$ and Concrete $\mathrm{E}$ respectively. Two of the fine aggregate samples were obtained from Otamiri and Njaba rivers while the other three samples were run-off sand from Awomama, Iho and Nekede (all in Imo State, Nigeria). Each fine aggregate sample was used to produce sixty concrete beam specimens which were tested for modulus of rupture giving a total of 300 concrete beams measuring $150 \times 150 \times 600, \mathrm{~mm}$ in dimension. Scheffe's simplex lattice design technique was used to formulate mathematical models for the determination of the modulus of rupture of the produced concrete beam specimens. The values of responses determined from the models agreed with the corresponding values obtained experimentally. The formulated models can predict all possible combinations of mix proportions if the value of modulus of rupture is given. Conversely, it can determine the modulus of rupture if a mix proportion is specified. The formulated models were tested for adequacy using $\mathrm{F}-$ statistic test. The models were found to be adequate. The highest optimum modulus of rupture predictable within the factor space of Scheffe's Simplex lattice design models is $9.99 \mathrm{~N} / \mathrm{mm}^{2}$ obtained from Sample D.

KEYWORDS: Simplex Lattice Design, Concrete Beams, Modulus of Rupture, Formulated Models, F- Statistic Test.

[Received October 3, 2018, Revised March 3, 2019, Accepted April 6, 2019]

Print ISSN: 0189-9546 | Online ISSN: 2437-2110

\section{INTRODUCTION}

The rate of development of infrastructure in Nigeria is dwindling because of the prohibitive cost of construction materials. Concrete, which is produced by combining water, cement and aggregates, is the most commonly used construction material in the world today. Concrete is used to produce various structural elements required to resist applied load (Obam, 2009). In order to reduce the cost of structural elements, Nigerians use various types of fine aggregate for construction purposes. Apart from river sand, they use run-off sand. The use of aggregates produces concrete with higher volume stability and better durability than hydrated cement paste alone.

All aggregates are generally believed to be reactive to some degree when used in Portland cement concrete, and some reaction evidence has been identified petrographically in many concrete that are performing satisfactorily (ACI, 2001; Taylor, 2013). ACI (2001) stated that a reaction is considered deleterious when it causes extensive expansion and produces cracking of the concrete. This work evaluates the modulus of rupture of concrete beam specimens made from fine aggregates sourced from two rivers and run-off sand from three locations. This research work also incorporates the formulation of mathematical models using Scheffe's simplex lattice design technique for the determination of modulus of rupture of concrete. The formulated models would predict the modulus of *Corresponding author: chinedu.ajoku@ futo.edu.ng rupture of concrete made from fine aggregate of similar characteristics.

Modulus of rupture, which is a measure of flexural strength, is the property of a solid that indicates its ability to resist bending. It is one of the basic parameters for computing deflection in reinforced concrete structures (Anbuvelan and Subramanian, 2014). The design of some structures like dams (under earthquake conditions), concrete pavement (such as highway) and airfield pavements, is often based on the modulus of rupture of concrete. Such structures are required to resist tensile stress from two main sources namely wheel loads and volume changes (Shetty, 2005).

Wheel loads may cause high tensile stress due to bending if there is an inadequate subgrade support. Volume changes as a result of variations in temperature and moisture may produce tensile stress due to warping and the movement of the slab along the subgrade. It is therefore necessary to assess the modulus of rupture of the concrete either from compressive strength or independently. Although concrete is not normally designed to resist direct tension, the knowledge of tensile strength is necessary in estimating the load under which cracking will occur (Neville, 2012). 
The application of statistical experimental design involves the use of theory of statistics and some specified laboratory results from practical experiments to formulate the mathematical model (equation) which will later be used to predict various responses. The responses may include workability, compressive strength, modulus of rupture, split tensile strength, durability, etc. Statistical mixture design methods based on experiments constitute a new application area and prove to be a useful tool in terms of providing cost effective means of the concrete optimization (Ozlem et al, 2010). The Scheffe Simplex Lattice design is an important statistical experimental design technique. Statistical experimental design has been studied by several researchers.

Wang and Chen (1997) studied the simplex - centroid design for determining the optimal proportions of admixture in concrete. They adopted the simplex - centroid design with upper and lower bounds of component proportions to study the compressive strength of mortars made with ternary blends of cement, ground granulated blast- furnace slag and fly ash. Seven design points and three cubic polynomial models were used to establish the strength predicting equations at different ages for the mortars. Onwuka et al. (2013) studied the use of Scheffe simplex $(5,2)$ lattice design in developing an optimization model for the compressive strength of sawdust ash-cement concrete. Their work was aimed at prediction and optimizing compressive strength of concrete when one of its conventional materials, cement is partially or wholly replaced by Sawdust ash.

The developed model was used to optimize the compressive strength of concrete made from water, cement, sawdust ash, sand and granites. Shafieyzadeh (2015) developed an empirical model to predict the flexural strength of silica fume-SBR concretes using concrete ingredients and time of curing in water. This research work has established the suitability of run-off and river sands obtained from five different locations in Imo State, Nigeria for the production of concrete for structural purposes and has developed five model equations for the prediction of modulus of rupture of concrete made from these fine aggregates.

\section{MATERIALS AND METHODS}

\section{A. Materials}

The materials used for this research include; Ibeto brand of ordinary Portland cement which conforms to the requirements of BS EN 197-1 (2011), fine aggregates (which includes river sand and run-off sand), coarse aggregate (granite chippings) and water. The river sand was obtained from two sources (Njaba and Otamiri Rivers) while the run-off sand was from three different localities (Awomama, Iho, Nekede) all in Imo State, South Eastern Nigeria. The physical properties of these fine aggregates are presented in Table 1. The coarse aggregate (crushed granite) was obtained from Ishiagu quarry site in Ebonyi State, Nigeria. The maximum grain size of the coarse aggregate was $20 \mathrm{~mm}$, it had a bulk density, specific gravity, water absorption and aggregate impact value of $2834 \mathrm{~kg} / \mathrm{m}^{3}, 2.83,1.6 \%$ and $21.27 \%$ respectively. Potable water for the work, which conforms to the requirements of BS EN 1008 (2002) was obtained from piped municipal water supply.
Table 1. Physical characteristics of fine aggregates.

\begin{tabular}{|c|c|c|c|c|c|}
\hline Characteristics & $\begin{array}{c}\text { Sample } \\
\text { A }\end{array}$ & $\begin{array}{c}\text { Sample } \\
\text { B }\end{array}$ & $\begin{array}{c}\text { Sample } \\
\text { C }\end{array}$ & $\begin{array}{c}\text { Sample } \\
\text { D }\end{array}$ & $\underset{\text { E }}{\text { Sample }}$ \\
\hline Type of sand & $\begin{array}{c}\text { River } \\
\text { sand }\end{array}$ & $\begin{array}{c}\text { Run-off } \\
\text { sand }\end{array}$ & $\begin{array}{c}\text { Run-off } \\
\text { sand }\end{array}$ & $\begin{array}{c}\text { Run-off } \\
\text { sand }\end{array}$ & $\begin{array}{l}\text { River } \\
\text { sand }\end{array}$ \\
\hline Specific gravity & 2.44 & 2.35 & 2.40 & 2.55 & 2.53 \\
\hline Bulk density & $\begin{array}{c}1940 \\
\mathrm{~kg} / \mathrm{m}^{3}\end{array}$ & $\begin{array}{c}1970 \\
\mathrm{~kg} / \mathrm{m}^{3}\end{array}$ & $\begin{array}{c}1930 \\
\mathrm{~kg} / \mathrm{m}^{3}\end{array}$ & $\begin{array}{c}1940 \\
\mathrm{~kg} / \mathrm{m}^{3}\end{array}$ & $\begin{array}{l}1960 \\
\mathrm{~kg} / \mathrm{m}^{3}\end{array}$ \\
\hline $\begin{array}{l}\% \text { passing } 0.075 \\
\text { sieve }\end{array}$ & 0.55 & 0.7 & 0.55 & 0.1 & 0.0 \\
\hline $\begin{array}{l}\text { Fineness Modulus } \\
\text { (FM) }\end{array}$ & 2.44 & 2.32 & 2.25 & 2.48 & 2.66 \\
\hline $\begin{array}{l}\text { Coefficient } \\
\text { Uniformity, } C_{u}\end{array}$ of & 3.88 & 2.97 & 3.21 & 4.11 & 2.54 \\
\hline $\begin{array}{l}\text { Coefficient } \\
\text { Curvature, } \mathrm{C}_{\mathrm{c}}\end{array}$ & 1.08 & 1.20 & 1.21 & 1.28 & 1.04 \\
\hline Range of Particles & $\begin{array}{l}<0.075- \\
5 \mathrm{~mm}\end{array}$ & $\begin{array}{l}<0.075- \\
5 \mathrm{~mm}\end{array}$ & $\begin{array}{l}<0.075- \\
5 \mathrm{~mm}\end{array}$ & $\begin{array}{c}<0.075- \\
5 \mathrm{~mm}\end{array}$ & $\begin{array}{l}0.075- \\
4.75 \mathrm{~mm}\end{array}$ \\
\hline Water absorption & $19.14 \%$ & $23.3 \%$ & $28 \%$ & $25.30 \%$ & $23.3 \%$ \\
\hline Zone & Zone 2 & Zone 1 & Zone 1 & Zone 2 & Zone 2 \\
\hline
\end{tabular}

\section{B. Methods}

The concrete specimens for flexural strength test were prepared in accordance with BS EN 12390-1 (2012). Sixty Concrete beams were cast in $150 \times 150 \times 600 \mathrm{~mm}$ steel moulds from each fine aggregate sample totalling three hundred beam specimen. The flexural stength test was done as specified by BS EN 12390-2 (2009). After 28 days from the day of production of concrete specimens, the cured samples were subjected to flexure using a symmetrical two-point loading flexural machine to the point of failure.The modulus of rupture is calculated using Eq. (1).

$$
\delta_{f}=P L / b d^{2}
$$

where, $P=$ Maximum load, $L=$ The distance between supporting rollers, $b$ and $d$ are the lateral dimensions of the beam.

Scheffe's Simplex Lattice was used in formulating mathematical models for the prediction of the modulus of rupture of concrete made from fine aggregates obtained from various sources. The formulated mathematical models were tested for adequacy using f- statistic protocol.

\section{Scheffe's Simplex Lattice Design}

In this work, Henry Scheffe's Simplex lattice design was used to formulate mathematical models which would be used to predict possible combinations of concrete components that will produce a specified modulus of rupture and vice versa. Thus, if a mixture has a total of $q$ components and $X_{i}$ (as given in Eq. (2)) be the proportions of the components (ingredients) of the $\mathrm{i}^{\text {th }}$ component in the mixture such that

$$
X_{i} \geq 0 \quad(i=1,2, \ldots \ldots q)
$$

and assuming the mixture to be a unit quantity, then the sum of all the proportions of the component must be unity as provided in Eq, (3). That is; 


$$
X_{1}+X_{2}+X_{3}+\cdots+X_{q-1}+X_{q}=1
$$

\section{1.) Scheffe's factor space}

Mix components are assumed to interact within a factor space. The concrete used in this research is a 4-component mixture, which was analyzed using a tetrahedron having a three-dimensional factor space. The tetrahedron is illustrated in Fig. 1.

\section{2.) Actual and pseudo components}

The pseudo components represent the proportions of the $\mathrm{i}^{\text {th }}$ component in the concrete mixture. At any point in the factor space, the summation of the pseudo components must be equal to one. No pseudo component is more than one or less than zero as represented in Eq. (4).

$$
0 \leq X_{i} \leq 1
$$

\section{3.) Four-Component mixture}

The four-component concrete mixture used for this work consist of water, cement, sand (obtained from five different sources) and granite chippings. The number of components, $\mathrm{q}$ is equal to four. The factor space used for the analysis is q-1, that is, three- dimensional factor space. The imaginary space used is shown in Fig. 1.

\section{4.) Equation for Actual and Pseudo Component Interaction}

Okere (2013) and Gamil \& Bakar (2016) provide an equation of Scheffe's elucidation of the relationship between the pseudo component and the actual component in their mixture designs. From Equations 5-8, the actual components of the mix design can be derived from the pseudo components and vice versa.

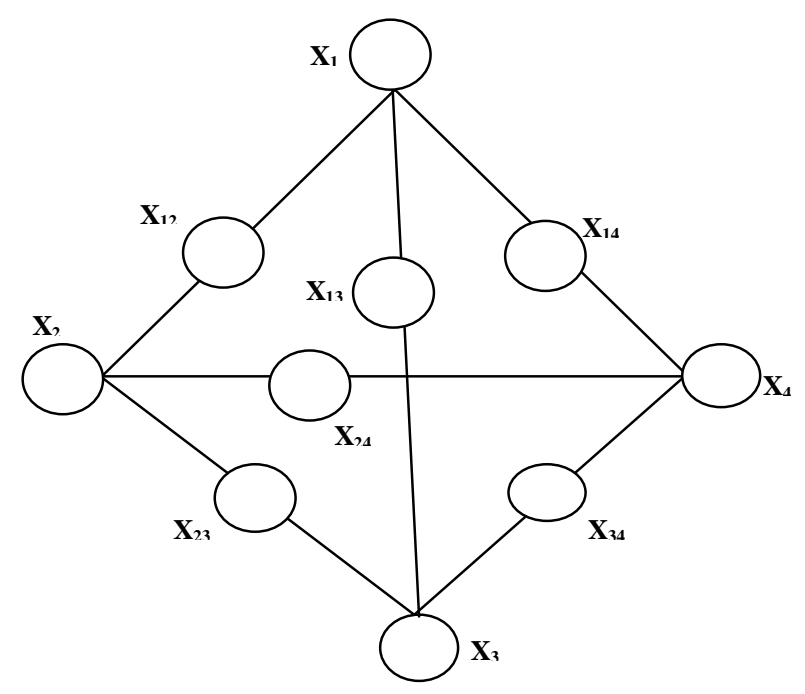

Let the pseudo component be $\mathrm{X}$ and actual component be $\mathrm{Z}$.

$$
[Z]=[A][X]
$$

where $[\mathrm{A}]$ is the matrix of coefficient

$$
[X]=[Z][A]^{-1}
$$

$$
\text { let, } \quad[A]^{-1}=[B]
$$

Therefore, $[X]=[B][Z]$

The actual components $[\mathrm{Z}]$ of the four-component mixture are determined by multiplying the values of matrix $[\mathrm{A}]$ with values of matrix $[\mathrm{X}]$ (pseudo components) as shown in Equation 5, the result of which is given in Equation 9.

$\left[\begin{array}{l}Z_{1} \\ Z_{2} \\ Z_{3} \\ Z_{4}\end{array}\right]=\left[\begin{array}{cccc}0.6 & 0.55 & 0.5 & 0.45 \\ 1 & 1 & 1 & 1 \\ 1.5 & 1 & 1.5 & 2 \\ 3 & 1 & 4 & 4\end{array}\right] X\left[\begin{array}{l}X_{1} \\ \boldsymbol{X}_{2} \\ \boldsymbol{X}_{3} \\ \boldsymbol{X}_{4}\end{array}\right]$

The pseudo components and the corresponding actual components at the different points on the factor space are shown in Table 2.

\begin{tabular}{cccccccccc}
\multicolumn{1}{l}{ Table 2: Values of Pseudo and Actual Components } \\
\hline $\mathbf{N}$ & $\mathbf{X}_{\mathbf{1}}$ & $\mathbf{X}_{\mathbf{2}}$ & $\mathbf{X}_{\mathbf{3}}$ & $\mathbf{X}_{\mathbf{4}}$ & Response & $\mathbf{Z}_{\mathbf{1}}$ & $\mathbf{Z}_{\mathbf{2}}$ & $\mathbf{Z}_{\mathbf{3}}$ & $\mathbf{Z}_{\mathbf{4}}$ \\
\hline 1 & 1 & 0 & 0 & 0 & $\mathrm{Y}_{1}$ & 0.6 & 1 & 1.5 & 3 \\
2 & 0 & 1 & 0 & 0 & $\mathrm{Y}_{2}$ & 0.55 & 1 & 1 & 1 \\
3 & 0 & 0 & 1 & 0 & $\mathrm{Y}_{3}$ & 0.50 & 1 & 1.5 & 4 \\
4 & 0 & 0 & 0 & 1 & $\mathrm{Y}_{4}$ & 0.45 & 1 & 2 & 4 \\
12 & 0.5 & 0.5 & 0 & 0 & $\mathrm{Y}_{12}$ & 0.575 & 1 & 1.25 & 2 \\
13 & 0.5 & 0 & 0.5 & 0 & $\mathrm{Y}_{13}$ & 0.55 & 1 & 1.5 & 3.5 \\
14 & 0.5 & 0 & 0 & 0.5 & $\mathrm{Y}_{14}$ & 0.525 & 1 & 1.75 & 3.5 \\
23 & 0 & 0.5 & 0.5 & 0 & $\mathrm{Y}_{23}$ & 0.525 & 1 & 1.25 & 2.5 \\
24 & 0 & 0.5 & 0 & 0.5 & $\mathrm{Y}_{24}$ & 0.5 & 1 & 1.5 & 2.5 \\
34 & 0 & 0 & 0.5 & 0.5 & $\mathrm{Y}_{34}$ & 0.475 & 1 & 1.75 & 4 \\
\hline
\end{tabular}

where, $\mathrm{X}_{1}, \mathrm{X}_{2}, \mathrm{X}_{3}$, and $\mathrm{X}_{4}$ are defined as pseudo components of water, cement, sand and granite chippings respectively and $\mathrm{Z}_{1}, \mathrm{Z}_{2}, \mathrm{Z}_{3}$, and $\mathrm{Z}_{4}$ are actual components of water, cement, sand and granite chippings respectively. $\mathrm{N}$ is any point on the factor space and $\mathrm{Y}$ is the response.

\section{5.) Control Points}

Ten control points used are $\mathrm{C}_{1}, \mathrm{C}_{2}, \mathrm{C}_{3}, \mathrm{C}_{4}, \mathrm{C}_{5}, \mathrm{C}_{6}, \mathrm{C}_{7}, \mathrm{C}_{8}$, $\mathrm{C}_{9}$, and $\mathrm{C}_{10}$. The actual components and the corresponding pseudo components are shown in Table 3.

Fig.1: Four component mixture in a three-dimensional factor space showing ten points of observation. 
Table 3: Actual and pseudo components at the control points.

\begin{tabular}{cccccccccc}
\hline $\mathbf{C}$ & $\mathbf{X}_{1}$ & $\mathbf{X}_{\mathbf{2}}$ & $\mathbf{X}_{\mathbf{3}}$ & $\mathbf{X}_{\mathbf{4}}$ & Responses & $\mathbf{Z}_{\mathbf{1}}$ & $\mathbf{Z}_{2}$ & $\mathbf{Z}_{3}$ & $\mathbf{Z}_{4}$ \\
\hline 1 & $1 / 2$ & $1 / 4$ & $1 / 4$ & 0 & $\mathrm{y}_{\mathrm{C} 1}$ & 0.5625 & 1 & 1.375 & 2.75 \\
2 & $1 / 4$ & $1 / 4$ & $1 / 4$ & $1 / 4$ & $\mathrm{y}_{\mathrm{C} 2}$ & 0.525 & 1 & 1.5 & 3 \\
3 & 0 & $3 / 4$ & 0 & $1 / 4$ & $\mathrm{y}_{\mathrm{C} 3}$ & 0.525 & 1 & 1.25 & 1.75 \\
4 & $1 / 2$ & $1 / 4$ & 0 & $1 / 4$ & $\mathrm{y}_{\mathrm{C} 4}$ & 0.55 & 1 & 1.5 & 2.75 \\
5 & $1 / 2$ & $1 / 4$ & $1 / 4$ & 0 & $\mathrm{y}_{\mathrm{C} 5}$ & 0.5625 & 1 & 1.375 & 2.75 \\
6 & 0 & $1 / 2$ & $1 / 4$ & $1 / 4$ & $\mathrm{y}_{\mathrm{C} 6}$ & 0.5125 & 1 & 1.375 & 2.5 \\
7 & $1 / 4$ & $1 / 8$ & $1 / 2$ & $1 / 8$ & $\mathrm{y}_{\mathrm{C} 7}$ & 0.525 & 1 & 1.5 & 3.375 \\
8 & $1 / 8$ & $1 / 8$ & $1 / 4$ & $1 / 2$ & $\mathrm{y}_{\mathrm{C} 8}$ & 0.49375 & 1 & 1.6875 & 3.5 \\
9 & $1 / 2$ & 0 & $1 / 4$ & $1 / 4$ & $\mathrm{y}_{\mathrm{C} 9}$ & 0.5375 & 1 & 1.625 & 3.5 \\
10 & $1 / 4$ & $1 / 4$ & $\mathrm{O}$ & $1 / 2$ & $\mathrm{y}_{\mathrm{C} 10}$ & 0.5125 & 1 & 1.625 & 3 \\
\hline
\end{tabular}

6.) Proportion of Concrete Constituents

The proportion of concrete constituents per beam sample is presented on Table 4.

Table 4. Mix proportions (actual components) per concrete beam.

\begin{tabular}{ccccccccc}
\hline Mix & $\mathbf{Z}_{1}$ & $\mathbf{Z}_{\mathbf{2}}$ & $\mathbf{Z}_{\mathbf{3}}$ & $\mathbf{Z}_{\mathbf{4}}$ & $\begin{array}{c}\text { Water } \\
(\mathbf{k g})\end{array}$ & $\begin{array}{c}\text { Cement } \\
(\mathbf{k g})\end{array}$ & $\begin{array}{c}\text { Sand } \\
(\mathbf{k g})\end{array}$ & $\begin{array}{c}\text { Granite } \\
\text { chippings } \\
(\mathbf{k g})\end{array}$ \\
\hline $\mathrm{N}_{1}$ & 0.6 & 1 & 1.5 & 3 & 3.68 & 6.14 & 9.20 & 18.42 \\
$\mathrm{~N}_{2}$ & 0.55 & 1 & 1 & 1 & 6.19 & 11.25 & 11.25 & 11.25 \\
$\mathrm{~N}_{3}$ & 0.50 & 1 & 1.5 & 4 & 2.60 & 5.19 & 7.79 & 20.77 \\
$\mathrm{~N}_{4}$ & 0.45 & 1 & 2 & 4 & 2.17 & 4.82 & 9.64 & 19.29 \\
$\mathrm{~N}_{12}$ & 0.575 & 1 & 1.25 & 2 & 4.57 & 7.94 & 9.93 & 15.88 \\
$\mathrm{~N}_{13}$ & 0.55 & 1 & 1.5 & 3.5 & 3.10 & 563 & 8.44 & 19.69 \\
$\mathrm{~N}_{14}$ & 0.525 & 1 & 1.75 & 3.5 & 2.84 & 5.40 & 9.45 & 18.90 \\
$\mathrm{~N}_{23}$ & 0.525 & 1 & 1.25 & 2.5 & 3.73 & 7.11 & 8.88 & 17.76 \\
$\mathrm{~N}_{24}$ & 0.5 & 1 & 1.5 & 2.5 & 3.38 & 6.75 & 10.13 & 16.88 \\
$\mathrm{~N}_{34}$ & 0.475 & 1 & 1.75 & 4 & 2.38 & 5.00 & 8.75 & 20.00 \\
& & & & & & & & \\
& & & & & & & & \\
$\mathrm{C}_{1}$ & 0.563 & 1 & 1.37 & 2.75 & 3.71 & 6.59 & 9.06 & 18.11 \\
& & & 5 & & & & & \\
$\mathrm{C}_{2}$ & 0.525 & 1 & 1.5 & 3 & 3.22 & 6.14 & 9.21 & 18.41 \\
$\mathrm{C}_{3}$ & 0.525 & 1 & 1.25 & 1.75 & 4.43 & 8.44 & 10.55 & 14.77 \\
$\mathrm{C}_{4}$ & 0.55 & 1 & 1.5 & 2.75 & 3.54 & 6.43 & 9.64 & 17.68 \\
$\mathrm{C}_{5}$ & 0.563 & 1 & 1.38 & 2.75 & 3.71 & 6.59 & 9.05 & 18.13 \\
$\mathrm{C}_{6}$ & 0.513 & 1 & 1.38 & 2.5 & 3.55 & 6.92 & 9.52 & 17.13 \\
$\mathrm{C}_{7}$ & 0.525 & 1 & 1.5 & 3.38 & 3.01 & 5.74 & 8.62 & 19.39 \\
$\mathrm{C}_{8}$ & 0.494 & 1 & 1.69 & 3.5 & 2.69 & 5.45 & 9.20 & 19.08 \\
$\mathrm{C}_{9}$ & 0.538 & 1 & 1.63 & 3.5 & 2.96 & 5.51 & 8.95 & 19.29 \\
$\mathrm{C}_{10}$ & 0.513 & 1 & 1.63 & 3 & 3.08 & 6.00 & 9.75 & 18.00 \\
\hline
\end{tabular}

\section{7.) Responses}

Arimanwa et al. (2012) developed a simplex lattice general equation for a five-component mixture of degree two given as Equation 10. This equation has been further reduced in this research work to a four-component mixture of degree two as shown in Equation 11.

$$
\begin{aligned}
Y=X_{1}\left(2 X_{1}-1\right) & y_{1}+X_{2}\left(2 X_{2}-1\right) y_{2}+X_{3}\left(2 X_{3}-1\right) y_{3} \\
& +X_{4}\left(2 X_{4}-1\right) y_{4}+X_{5}\left(2 X_{5}-1\right) y_{5} \\
& +4 y_{12} X_{1} X_{2}+4 y_{13} X_{1} X_{3}+4 y_{14} X_{1} X_{4} \\
& +4 y_{15} X_{1} X_{5}+4 y_{23} X_{2} X_{3}+4 y_{24} X_{2} X_{4} \\
& +4 y_{25} X_{2} X_{5}+4 y_{34} X_{3} X_{4}+4 y_{35} X_{3} X_{5} \\
& +4 y_{45} X_{4} X_{5}+e
\end{aligned}
$$

$$
\begin{aligned}
Y=X_{1}\left(2 X_{1}-1\right) & y_{1}+X_{2}\left(2 X_{2}-1\right) y_{2}+X_{3}\left(2 X_{3}-1\right) y_{3} \\
& +X_{4}\left(2 X_{4}-1\right) y_{4}+4 y_{12} X_{1} X_{2} \\
& +4 y_{13} X_{1} X_{3}+4 y_{14} X_{1} X_{4}+4 y_{23} X_{2} X_{3} \\
& +4 y_{24} X_{2} X_{4}+4 y_{34} X_{3} X_{4}+e
\end{aligned}
$$

Equation (11) is the mixture design model for the determination of a concrete mixture consisting of four components. The terms $\mathrm{y}_{\mathrm{i}}$ and $\mathrm{y}_{\mathrm{ij}}$ are responses (representing concrete mechanical properties) at the point $\mathrm{i}$ and $\mathrm{ij}$. These responses are determined by carrying out laboratory tests. Where, $\mathrm{X}_{\mathrm{i}}$, and $\mathrm{X}_{\mathrm{j}}$ represent the pseudo components and $\mathrm{e}$ is the random error term, which represents the combine effects of all variables not included in the model.

\section{RESULTS AND DISCUSSION}

\section{A. Presentation of Results}

The results obtained from the modulus of rupture experiment performed in this research work are presented in Table 5. Concrete A is Njaba River sand concrete, Concrete B is Awomama run-off sand concrete, Concrete $\mathrm{C}$ is Iho run-off sand concrete, Concrete D is Nekede run-off sand concrete, Concrete E is Otamiri River sand concrete.

Table 5: Mean Modulus of rupture laboratory test results of concrete beams.

\begin{tabular}{ccccccc}
\hline S/N & $\begin{array}{c}\text { Points of } \\
\text { Observation }\end{array}$ & $\begin{array}{c}\text { Concrete } \\
\text { A }\end{array}$ & $\begin{array}{c}\text { Concrete } \\
\text { B }\end{array}$ & $\begin{array}{c}\text { Concrete } \\
\text { C }\end{array}$ & $\begin{array}{c}\text { Concrete } \\
\text { D }\end{array}$ & $\begin{array}{c}\text { Concrete } \\
\text { E }\end{array}$ \\
\hline 1 & N1 & 6.35 & 7.98 & 6.53 & 6.34 & 4.32 \\
2 & N2 & 5.23 & 9.37 & 9.9 & 3.41 & 4 \\
3 & N3 & 6.94 & 9.18 & 8.26 & 7.94 & 5.6 \\
4 & N4 & 4.35 & 6.4 & 8.3 & 4.88 & 3.27 \\
5 & N12 & 6.65 & 7.54 & 7.82 & 9.59 & 3.41 \\
6 & N13 & 8.45 & 8.68 & 5.23 & 9.99 & 5.55 \\
7 & N14 & 5.67 & 7.86 & 7.4 & 5.4 & 4.08 \\
8 & N23 & 5.92 & 8.8 & 7.6 & 5.11 & 5.53 \\
9 & N24 & 3.42 & 8.04 & 5.69 & 4.48 & 5.53 \\
10 & N34 & 7.28 & 5.45 & 5.31 & 4.49 & 4.8 \\
& & & Control Points & & & \\
11 & C1 & 7.42 & 7.86 & 6.18 & 9.36 & 5.04 \\
12 & C2 & 6.28 & 7.95 & 6 & 6.64 & 5.19 \\
13 & C3 & 3.59 & 8.36 & 6.4 & 4.2 & 5.52 \\
14 & C4 & 5.92 & 7.25 & 7.8 & 7.52 & 4.16 \\
15 & C5 & 7.1 & 8.3 & 6.16 & 9.33 & 4.54 \\
16 & C6 & 5.76 & 7.4 & 5.53 & 4.24 & 5.7 \\
17 & C7 & 7.03 & 8.08 & 5.99 & 7.51 & 4.88 \\
18 & C8 & 7 & 7.02 & 5.28 & 4.95 & 5.25 \\
19 & C9 & 6.8 & 7.79 & 5.66 & 6.48 & 4.83 \\
20 & C10 & 5.08 & 8.36 & 7 & 6.25 & 4.93 \\
\hline
\end{tabular}

\section{B. Discussion of Results}

B.1 Modulus of Rupture of Concrete Samples

Flexural strength test is performed to estimate the tensile load at which concrete may crack. The theoretical maximum 
tensile stress reached in the bottom fibre of the test beam is known as modulus of rupture. Modulus of rupture is a function of bending resistance of a concrete beam section. The design of dams (under earthquake conditions) and concrete slabs such as highway and airfield pavements are often based on the flexural strength of concrete because the structures are significantly subject to bending in service.

Experimental results showed that different Moduli of Rupture were obtained for concrete produced from sand samples from different sources. The range of values are: 3.42 - 8.45 N/mm $\mathrm{mm}^{2}$ for Njaba River sand concrete (Concrete A), $5.45-9.37 \mathrm{~N} / \mathrm{mm}^{2}$ for Awomama run-off sand concrete (Concrete B), $5.23-9.90 \mathrm{~N} / \mathrm{mm}^{2}$ for Iho run-off sand concrete (Concrete C), $3.41-9.99 \mathrm{~N} / \mathrm{mm}^{2}$ for Nekede run-off sand concrete (Concrete D) and $\quad 3.27-5.60 \mathrm{~N} / \mathrm{mm}^{2}$ for Otamiri River sand concrete (Concrete E)

This research aimed at showing the suitability of run-off sand in concrete production and formulation of models for the determination of Modulus of Rupture of concrete using sand from different sources. The obtained Modulus of Rupture value ranges indicate that sand from run-off sources produced concrete comparable to the regular river sand concrete. Sample D produced the maximum Modulus of Rupture of $9.99 \mathrm{~N} / \mathrm{mm}^{2}$ at observation point $\mathrm{N}_{13}$, which makes it the recommended sample when flexural strength is critical. Sample E produced the minimum value of $3.27 \mathrm{~N} / \mathrm{mm}^{2}$. The result of this research shows that the order of preference when flexural strength is critical is Concrete D, C, B, A, and E. Models were effectively formulated for the determination of Modulus of Rupture of concrete at different observation points using sand samples obtained from the referred sources. The formulated models can be used for the determination of Modulus of Rupture of concrete produced from sand samples from any other locality provided such samples have similar characteristics to the ones used in this work.

\section{B.2 Determination of Scheffe's Simplex Model}

The Scheffe simplex model used to generate the predicted values of modulus of rupture given in Table 6 is obtained by substituting the values of the mechanical properties test results from the laboratory (responses, $\mathrm{y}_{\mathrm{i}}$ ), presented on Tables 4 into the Scheffe's general equation for a four-component mixture given in eqn (11). This mathematical operation yields Equations (12-16) for the prediction of flexural strengths properties of concrete realised from local fine aggregates obtained from five different localities.

$$
\begin{aligned}
& \text { Concrete } A \\
& \begin{aligned}
Y=6.35 X_{1}\left(2 X_{1}\right. & -1)+5.23 X_{2}\left(2 X_{2}-1\right) \\
& +6.94 X_{3}\left(2 X_{3}-1\right)+4.35 X_{4}\left(2 X_{4}-1\right) \\
& +26.6 X_{1} X_{2}+33.80 X_{1} X_{3}+22.68 X_{1} X_{4} \\
& +23.68 X_{2} X_{3}+13.68 X_{2} X_{4}+29.12 X_{3} X_{4} \\
& +e
\end{aligned}
\end{aligned}
$$

\section{Concrete $B$}

$$
\begin{aligned}
Y=7.98 X_{1}\left(2 X_{1}\right. & -1)+9.37 X_{2}\left(2 X_{2}-1\right) \\
& +9.18 X_{3}\left(2 X_{3}-1\right)+6.40 X_{4}\left(2 X_{4}-1\right) \\
& +30.16 X_{1} X_{2}+34.72 X_{1} X_{3}+31.44 X_{1} X_{4} \\
& +35.20 X_{2} X_{3}+32.16 X_{2} X_{4}+21.80 X_{3} X_{4} \\
& +e
\end{aligned}
$$

\section{Concrete $C$}

$$
\begin{aligned}
Y=6.53 X_{1}\left(2 X_{1}\right. & -1)+9.90 X_{2}\left(2 X_{2}-1\right) \\
& +8.26 X_{3}\left(2 X_{3}-1\right)+8.30 X_{4}\left(2 X_{4}-1\right) \\
& +31.28 X_{1} X_{2}+20.92 X_{1} X_{3}+29.60 X_{1} X_{4} \\
& +30.40 X_{2} X_{3}+22.76 X_{2} X_{4}+21.24 X_{3} X_{4} \\
& +e
\end{aligned}
$$

\section{Concrete D}

$$
\begin{aligned}
Y=6.34 X_{1}\left(2 X_{1}\right. & -1)+3.41 X_{2}\left(2 X_{2}-1\right) \\
& +7.94 X_{3}\left(2 X_{3}-1\right)+4.88 X_{4}\left(2 X_{4}-1\right) \\
& +38.36 X_{1} X_{2}+39.96 X_{1} X_{3}+21.60 X_{1} X_{4} \\
& +20.44 X_{2} X_{3}+17.92 X_{2} X_{4}+17.96 X_{3} X_{4} \\
& +e
\end{aligned}
$$

$$
\begin{aligned}
& \text { Concrete } E \\
& \qquad \begin{aligned}
Y=4.32 X_{1}\left(2 X_{1}\right. & -1)+4.00 X_{2}\left(2 X_{2}-1\right) \\
& +5.60 X_{3}\left(2 X_{3}-1\right)+3.27 X_{4}\left(2 X_{4}-1\right) \\
& +13.64 X_{1} X_{2}+22.20 X_{1} X_{3}+16.32 X_{1} X_{4} \\
& +22.12 X_{2} X_{3}+22.12 X_{2} X_{4}+19.20 X_{3} X_{4} \\
& +e
\end{aligned}
\end{aligned}
$$

The optimum predictable responses obtained within the factor space of Scheffe's Simplex models are presented in Table 6 . The values of modulus of rupture realized by substituting the pseudo mix ratios in Table 1 into Equations 1216 are presented in Table 7 alongside the results from the laboratory experiments. The models were tested for "goodness of fit" to ensure that they are adequate for use.

Table 6. Optimum predictable responses obtained within the factor space of Scheffe's simplex models.

\begin{tabular}{llllll}
\hline & $\begin{array}{c}\text { Concrete } \\
\text { A }\end{array}$ & $\begin{array}{c}\text { Concrete } \\
\text { B }\end{array}$ & $\begin{array}{c}\text { Concrete } \\
\text { C }\end{array}$ & $\begin{array}{c}\text { Concrete } \\
\text { D }\end{array}$ & $\begin{array}{c}\text { Concrete } \\
\text { E }\end{array}$ \\
\hline $\begin{array}{l}\text { Modulus } \\
\text { of Rupture }\end{array}$ & 8.45 & 9.37 & 9.90 & 9.99 & 5.69 \\
\hline
\end{tabular}


Table 7. Results of the modulus of rupture test and Scheffe's simplex model.

\begin{tabular}{|c|c|c|c|c|c|c|c|c|c|c|}
\hline \multirow[t]{2}{*}{$\mathbf{P}$} & \multicolumn{2}{|c|}{ Concrete A } & \multicolumn{2}{|c|}{ Concrete B } & \multicolumn{2}{|c|}{ Concrete $\mathrm{C}$} & \multicolumn{2}{|c|}{ Concrete D } & \multicolumn{2}{|c|}{ Concrete E } \\
\hline & $\mathbf{F}$ & $\mathbf{G}$ & $\mathbf{F}$ & $\mathbf{G}$ & $\mathbf{F}$ & $\mathbf{G}$ & $\mathbf{F}$ & $\mathbf{G}$ & $\mathbf{F}$ & $\mathbf{G}$ \\
\hline $\mathbf{N}_{1}$ & 6.35 & 6.35 & 7.98 & 7.98 & 6.53 & 6.53 & 6.34 & 6.34 & 4.32 & 4.32 \\
\hline $\mathbf{N}_{2}$ & 5.23 & 5.23 & 9.37 & 9.37 & 9.90 & 9.90 & 3.41 & 3.41 & 4.00 & 4.00 \\
\hline $\mathbf{N}_{3}$ & 6.94 & 6.94 & 9.18 & 9.18 & 8.26 & 8.26 & 7.94 & 7.94 & 5.60 & 5.60 \\
\hline $\mathbf{N}_{4}$ & 4.35 & 4.35 & 6.40 & 6.40 & 8.30 & 8.30 & 4.88 & 4.88 & 3.27 & 3.27 \\
\hline $\mathbf{N}_{12}$ & 6.65 & 6.65 & 7.54 & 7.54 & 7.82 & 7.82 & 9.59 & 9.59 & 3.41 & 3.41 \\
\hline $\mathbf{N}_{13}$ & 8.45 & 8.45 & 8.68 & 8.68 & 5.23 & 5.23 & 9.99 & 9.99 & 5.55 & 5.55 \\
\hline $\mathbf{N}_{14}$ & 5.67 & 5.67 & 7.86 & 7.86 & 7.40 & 7.40 & 5.40 & 5.40 & 4.08 & 4.08 \\
\hline $\mathbf{N}_{23}$ & 5.92 & 5.92 & 8.80 & 8.80 & 7.60 & 7.60 & 5.11 & 5.11 & 5.53 & 5.53 \\
\hline $\mathbf{N}_{24}$ & 3.42 & 3.42 & 8.04 & 8.04 & 5.69 & 5.69 & 4.48 & 4.48 & 5.53 & 5.53 \\
\hline $\mathbf{N}_{34}$ & 7.28 & 7.28 & 5.45 & 5.45 & 5.31 & 5.31 & 4.49 & 4.49 & 4.80 & 4.80 \\
\hline \multicolumn{11}{|c|}{ Control points } \\
\hline $\mathrm{C}_{1}$ & 7.42 & 7.51 & 7.86 & 7.99 & 6.18 & 6.16 & 9.36 & 9.65 & 5.04 & 4.66 \\
\hline $\mathrm{C}_{2}$ & 6.28 & 6.49 & 7.95 & 7.48 & 6.00 & 5.64 & 6.64 & 6.94 & 5.19 & 5.08 \\
\hline $\mathbf{C}_{3}$ & 3.59 & 3.98 & 8.36 & 8.74 & 6.40 & 6.94 & 4.20 & 4.03 & 5.52 & 5.24 \\
\hline $\mathrm{C}_{4}$ & 5.92 & 5.82 & 7.25 & 7.74 & 7.80 & 6.76 & 7.52 & 7.58 & 4.16 & 4.22 \\
\hline $\mathrm{C}_{5}$ & 7.10 & 7.51 & 8.30 & 7.99 & 6.16 & 6.16 & 9.33 & 9.65 & 4.54 & 4.66 \\
\hline $\mathrm{C}_{6}$ & 5.76 & 5.08 & 7.40 & 7.84 & 5.53 & 5.90 & 4.24 & 4.32 & 5.70 & 5.62 \\
\hline $\mathbf{C}_{7}$ & 7.03 & 7.59 & 8.08 & 7.85 & 5.99 & 5.58 & 7.51 & 7.98 & 4.88 & 5.42 \\
\hline $\mathrm{C}_{8}$ & 7.00 & 4.31 & 7.02 & 6.58 & 5.28 & 5.45 & 4.95 & 5.30 & 5.25 & 4.92 \\
\hline $\mathrm{C}_{9}$ & 6.80 & 6.18 & 7.79 & 7.69 & 5.66 & 5.57 & 6.48 & 7.22 & 4.83 & 4.91 \\
\hline $\mathrm{C}_{10}$ & 5.08 & 4.76 & 8.36 & 7.67 & 7.00 & 6.45 & 6.25 & 6.12 & 4.93 & 4.62 \\
\hline
\end{tabular}

Where $\mathrm{F}=$ modulus of rupture results obtained from experimental investigation measured in $\mathrm{N} / \mathrm{mm}^{2} ; \mathrm{G}=$ modulus of rupture results obtained from Scheffe's model; $\mathrm{P}=$ Point of observation.

\section{B.3 Test for Adequacy of the Models}

The test for goodness of fit for Concrete A shown in Table 8 is carried out using Fisher's test. Fisher's statistical tool was used to compare the predicted control values of modulus of rupture which were not involved in the formulation of the model equations and control results from the experiment. This condition, 1/F $<S_{1}^{2} / S_{2}{ }^{2}<F$ provided by Fisher must be satisfied for the developed model equation to be considered adequate.

Where $\mathrm{F}$ is Fisher value at 5\% significance level or $95 \%$ confidence level, $S_{1}$ is the larger value between $S_{p}$ and $S_{m}\left(S_{2}\right.$ is the smaller value between $S_{p}$ and $S_{m}$ ).
$\mathrm{S}_{\mathrm{p}}^{2}=\Sigma\left(\mathrm{Y}_{\mathrm{p}}-\ddot{\mathrm{Y}}_{\mathrm{p}}\right)^{2} /(\mathrm{N}-1)=12.33216 /(10-1)=1.37$

$\mathrm{S}_{\mathrm{M}^{2}}=\Sigma\left(\mathrm{Y}_{\mathrm{M}^{-}} \ddot{\mathrm{Y}}_{\mathrm{M}}\right)^{2} /(\mathrm{N}-1)=15.57264 /(10-1)=1.73$

Therefore, $\mathrm{S}_{1}{ }^{2}=1.73$ and $\mathrm{S}_{2}{ }^{2}=1.37$

$\mathrm{F}_{\text {calculated }}=\mathrm{S}_{1}{ }^{2} / \mathrm{S}_{2}{ }^{2}=1.73 / 1.37=1.26$

From F-Statistic table, $\mathrm{F}_{0.05}(9,9)=3.18 ; 1 / \mathrm{F}_{0.05}(9,9)=0.31$ Therefore, $0.31<1.26<3.18$,

Thus, the condition $1 / \mathrm{F}<\mathrm{S}_{1}{ }^{2} / \mathrm{S}_{2}{ }^{2}<\mathrm{F}$ has been satisfied. The difference between laboratory results and model results is not significant.

This procedure is repeated for Concrete $\mathrm{B}, \mathrm{C}, \mathrm{D}$ and $\mathrm{E}$ and the values of calculated $\mathrm{F}$ obtained are 1.22, 1.98, 1.13 and 1.15 respectively. The calculated $\mathrm{F}$ values from the statistical analysis satisfy the condition $1 / \mathrm{F}<\mathrm{S}_{1}{ }^{2} / \mathrm{S}_{2}{ }^{2}<\mathrm{F}$, this implies that the formulated equations are adequate in predicting the flexural strengths (modulus of rupture) of concrete made from fine aggregate of similar characteristics or any other concrete of similar constituents whose mix ratio falls within the designed simplex lattice structure of this research at 5\% significance level or $95 \%$ confidence level. 
Table 8. Modulus of rupture for Concrete A.

\begin{tabular}{lrrrrrr}
\hline $\begin{array}{c}\text { Response } \\
\text { symbol }\end{array}$ & \multicolumn{1}{l}{$\mathbf{Y}_{\mathbf{P}}$} & $\mathbf{Y}_{\mathbf{M}}$ & $\mathbf{Y}_{\mathbf{P}}-\ddot{\mathbf{y}}_{\mathbf{P}}$ & $\mathbf{Y}_{\mathbf{M}}-\ddot{\mathbf{y}}_{\mathbf{M}}$ & $\left(\mathbf{Y}_{\mathbf{P}}-\ddot{\mathbf{Y}}_{\mathbf{p}}\right)^{2}$ & $\left(\mathbf{Y}_{\mathbf{M}}-\ddot{\mathbf{y}}_{\mathbf{M}}\right)^{2}$ \\
\hline C1 & 7.42 & 7.51 & 1.222 & 1.266 & 1.493284 & 1.602756 \\
$\mathrm{C} 2$ & 6.28 & 6.49 & 0.082 & 0.246 & 0.006724 & 0.060516 \\
$\mathrm{C} 3$ & 3.59 & 3.98 & -2.608 & -2.264 & 6.801664 & 5.125696 \\
C4 & 5.92 & 5.82 & -0.278 & -0.424 & 0.077284 & 0.179776 \\
C5 & 7.10 & 7.51 & 0.902 & 1.266 & 0.813604 & 1.602756 \\
C6 & 5.76 & 5.08 & -0.438 & -1.164 & 0.191844 & 1.354896 \\
C7 & 7.03 & 7.59 & 0.832 & 1.346 & 0.692224 & 1.811716 \\
C8 & 7.00 & 7.52 & 0.802 & 1.276 & 0.643204 & 1.628176 \\
C9 & 6.80 & 6.18 & 0.602 & -0.064 & 0.362404 & 0.004096 \\
C10 & 5.08 & 4.76 & -1.118 & -1.484 & 1.249924 & 2.202256 \\
Total & 61.98 & 62.44 & & & 12.33216 & 15.57264 \\
Mean & 6.20 & 6.244 & & & & \\
\hline
\end{tabular}

\section{CONCLUSIONS}

This research work has the following conclusions;

a) Scheffe's simplex model has been applied accurately to develop mathematical models for a four-component concrete mix to predict and optimize the modulus of rupture of concrete made from five local fine aggregates obtained from different sources.

b) The modulus of rupture/ flexural strength results realized from the experiment has shown that river sand and run-off sand could interchangeably be used in construction in a locality where it proves to be relatively cheap.

c) Fisher's statistical test has been successfully used to establish the adequacy of the model equations derived in this experiment. This implies that these equations could reliably be used to forecast the flexural strength of any given mix ratio within the factor space developed in this experiment and which has constituent material properties similar to the ones used in this research.

\section{REFERENCES}

ACI 221 R-96. (2001). Guide for Use of Normal Weight and Heavy Weight Aggregates. ACI Manual of Concrete Practice - Part 1, American Concrete Institute, Farmngton Hills, M.I p. 7.

Anbuvelan, K. and Subramanian, K. (2014). An empirical relationship between modulus of elasticity, modulus of rupture and compressive strength of M60 concrete containing metakaolin, Res. J. Appl. Sci. Eng. Technol. 8 (11): 1294-1298.

Arimanwa, J. I; D. O. Onwuka; M. C. Arimanwa and U. S. Onwuka. (2012). Prediction of the Compressive Strength of Aluminium Waste-Cement Using Scheffe's Theory. Journal of Materials in Civil Engineering, 24: 177183.
BS EN 197. (2011). Cement. Composition, Specifications and Conformity Criteria for Common Cements. Part 1, London: British Standard Institution.

BS EN 1008. (2002). Mixing Water for Concrete. Specification for Sampling, Testing and Assessing the Suitability of Water, Including Water recovered from Processes in the Concrete Industry, as Mixing Water for Concrete. London: British Standard Institution.

BS EN 12390. (2012). Testing Hardened Concrete. Shape, Dimensions and Other Requirements for Specimens and Moulds. Part 1, London: British Standard Institution.

BS EN 12390. (2009). Testing Hardened Concrete. Making and Curing Specimens for Strength Tests. Part 2, London: British Standard Institution.

Gamil, Y. M. R. and Bakar I. H. (2016). The Development of Mathematical Prediction Model to Predict Resilient Modulus for Natural Soil Stabilized by Pofa-OPC Additive for the Use in Unpaved Road Design, IOP conference Series Materials Science and Engineering, 136(1): 1-11.

Neville, A. M. (2012). Properties of Concrete. Fifth Edition. Pearson. Harlow, England.

Obam, S. O. (2009). A Mathematical Model for Optimization of Strength of Concrete: A Case Study for Shear Modulus of Rice Husk Ash Concrete. Journal of Industrial Engineering International, 9: 76-84.

Okere, C. E. (2013). Optimization of Modulus of Rupture of Concrete Using Scheffe's Simplex Theory. International Journal of Advanced Technology and Engineering Research, 3: $1-6$.

Onwuka, D. O; L. Anyaogu; T. U. Anyanwu and C. Chijioke. (2013). Modeling of the Compressive Strength of River Sand-Termite Soil Concrete Using Osadebe's SecondDegree Polynomial Function. International Journal of Scientific and Research Publications, 3(5): 1-11.

Ozlem, A; U. A. Kadri and S. Bahar. (2010). SelfConsolidating High Strength Concrete Optimization by Mixture Design Method. All Business.com. Retrieved 28/12/2011 12:44pm.

Shafieyzadeh, M. J. (2015). Prediction of Flexural Strengths of Concretes Containing Silica Fume, and StyreneButadiene Rubber (SBR) with an empirical model. Journal of Institution Engineers (india): Series A, 96: 349 -355.

Shetty, M. S. (2005). Concrete Technology Theory and Practice. Revised Edition. S. Chand and Company Ltd. New Delhi.

Taylor, P. C. (2013). Curing Concrete. CRC Press, Florida.

Wang, D. and Chen, Z. (1997). On Predicting Compressive Strength of Mortar with Ternary Blends of Cement, GGBFs and Fly Ash. Cement and Concrete Research, 27: 487-493. 